\author{
SULFOMYCINS, A SERIES OF NEW \\ SULFUR-CONTAINING ANTIBIOTICS. I \\ ISOLATION, PURIFICATION AND PROPERTIES \\ Yoshiyuki Egawa, Kimio Umino, Yoshikazu Tamura, \\ Masaaki Shimizu, Kenyo Kaneko, Masaharu Sakurazawa, \\ Shigemi Awataguchi* and Tomoharu OKuda \\ Microbial Chemistry Research Laboratory and \\ Biological Research Laboratory* \\ Tanabe Seiyaku Co., Ltd., Toda, Saitama, Japan \\ (Received for publication November 19, 1968)
}

\begin{abstract}
Isolation of a series of antibiotics produced by a new variety of Streptomyces viridochromogenes was attempted, and three main components were obtained as amorphous powders. They were primarily active against Grampositive bacteria, anaerobic bacteria and mycoplasma and characterized as new members of sulfur-containing peptidic antibiotics. The antibiotic complex was named sulfomycin.
\end{abstract}

In the course of a screening program for antibiotics, a new variety of Streptomyces viridochromogenes (strain No. MCRL-0368) was found to produce a series of antibiotics primarily active against Gram-positive bacteria. The antibiotics with similar properties to each other were characterized as new members of sulfur-containing peptidic antibiotics, and named sulfomycin.

The present paper deals with isolation, purification, physicochemical and biological properties of three main components, sulfomycin I, II and III. Taxonomic studies on the sulfomycin-producing strain named Streptomyces viridochromogenes var. sulfomycini nov. var. will be reported later.

\title{
Isolation and Purification
}

During the isolation and purification process, antibacterial activity was assayed by cup-plate or paper-disc method with Bacillus subtilis PCI 219 as a test organism and using the purest sample of sulfomycin I as a standard material.

As a starting material, 120-hour culture was used which was obtained by submerged-cultivation of the strain MCRL-0368 at $27^{\circ} \mathrm{C}$ in a liquid medium composed of glucose $4 \%$, sucrose $2 \%$ and cotton seed meal $3 \%(\mathrm{pH} \mathrm{7.0).} \mathrm{Since} \mathrm{the} \mathrm{antibacterial}$ activity was observed not only in the culture liquid but also in the mycelium, the whole broth $(\mathrm{pH} 7 ; 80$ liters $; 100 \mathrm{mcg} / \mathrm{ml})$ was agitated with talc $(1.6 \mathrm{~kg})$ and Celite $545(1.6 \mathrm{~kg})$ and filtered with the aid of additional Celite $545(5.0 \mathrm{~kg})$. The cake collected was extracted twice with each 20 liters of acetone. The extract was concentrated in vacuo and the remaining aqueous solution (7 liters) was extracted twice with each 5 liters of ethyl acetate at $\mathrm{pH}$ 7.0. The extract (8.1 liters) was concentrated under reduced pressure to about 1 liter. The concentrate, after 
Fig. 1. Thin-layer chromatographic behavior of sulfomycin I, II and III.

Kieselgel $\mathrm{GF}_{254}, \mathrm{CHCl}_{3}-\mathrm{MeOH}$ $(10: 1)$

Detection by UV quenching

A : crude powder of sulfomycin complex.

B : sulfomycin I.

C : sulfomycin II.

D : sulfomycin III.

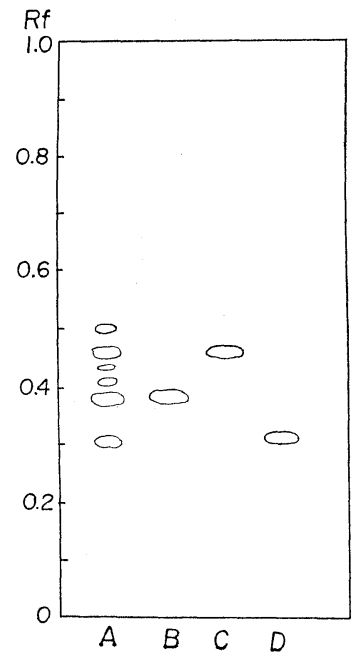

Table 1. Silicagel chromatography of sulfomycin mixture*

\begin{tabular}{r|c|c|c}
\hline $\begin{array}{c}\text { Fraction No. } \\
\text { of eluates }\end{array}$ & $\begin{array}{c}\text { Rf value of active } \\
\text { principle(s) in the } \\
\text { eluate** }\end{array}$ & $\begin{array}{c}\text { Material } \\
\text { recovered } \\
(\mathrm{mg})\end{array}$ & $\begin{array}{c}\text { MIC*** } \\
(\mathrm{mcg} / \mathrm{ml})\end{array}$ \\
\hline $83 \sim 119$ & 0.49 & 9.5 & 25 \\
$120 \sim 145$ & 0.46 (sulfomycin II) & 220 & 0.2 \\
$146 \sim 184$ & $0.46,0.44,0.42$ & 205 & 3.1 \\
$185 \sim 189$ & 0.42 & 16 & 1.0 \\
$198 \sim 230$ & 0.38 (sulfomycin I) & 1,800 & 0.1 \\
$305 \sim 350$ & 0.30 (sulfomycin III) & 30 & 6.25 \\
\hline
\end{tabular}

* Silicagel (Kieselgel G) : $400 \mathrm{~g}$. Column size : $60 \times 495 \mathrm{~mm}$. Temp. : $15^{\circ} \mathrm{C}$.

Sulfomycin mixture used : $8,000 \mathrm{mg}$.

Volume of each fraction collected : $20 \mathrm{ml}$.

** Rf value on thin-layer chromatogram with Kieselgel

$\mathrm{GF}_{254}$ (Solvent system : $\mathrm{CHCl}_{3}-\mathrm{MeOH}(10: 1)$ ).

*** Minimum inhibitory concentration against $B$. subtilis PCI 219 (Serial dilution method).

decolorization with aluminum oxide, was further evaporated in vacuo to give a syrup $(30 \mathrm{ml})$, which solidified. by treatment with $200 \mathrm{ml}$ of ether. The solid material was collected and dried. Thus, the crude powder (12 g, $520 \mathrm{mcg} / \mathrm{mg}$ ) of sulfomycin complex was obtained with over all recovery yield of about $78 \%$. Thin-layer chromatography with Kieselgel $\mathrm{GF}_{254}$ (solvent system : $\mathrm{CHCl}_{3}-\mathrm{MeOH}(10: 1$ ), detection by UV lamp and bioautography) indicated that the crude powder was consisted of several biologically active principles showing $\mathrm{Rf}$ values of $0.30,0.38,0.42,0.44,0.46$ and 0.49 (Fig. 1). The components showing $\mathrm{Rf}$ values at $0.38,0.46$ and 0.30 were the major components and designated sulfomycin I, II and III respectively.

Separation of each component was achieved by column chromatography with Kieselgel G (Merck) previously moistened with water and dried in air overnight. After washing the column with chloroform, development was made with a mixture of methanol and chloroform $(3: 100, \mathrm{v} / \mathrm{v})$. Fractions of the eluates were monitored by thin-layer chromatography and bioautography. Active component(s) were recovered from the eluate by concentration followed by solidification of the resulting syrup with ethyl ether. Thus, starting from $8 \mathrm{~g}$ of crude powder, 1,800 $\mathrm{mg}$ of sulfomycin. I, $220 \mathrm{mg}$ of sulfomycin II and $30 \mathrm{mg}$ of sulfomycin III were recovered as shown in. Table 1. Attempts to crystallize the sulfomycins failed, so that further purification. of the material was carried out by reprecipitation with acetone and ether.

\section{Physicochemical Properties}

Some of the physicochemical properties of sulfomycin I, II and III are summarized. in Table 2. The ultraviolet and infrared absorption spectra are shown in Figs. 2 and 3, and NMR spectrum of $\mathrm{I}$ in Fig. 4. Based upon analytical data, empirical formulae $\mathrm{C}_{55 \sim 57} \mathrm{H}_{56 \sim 64} \mathrm{~N}_{15 \sim 17} \mathrm{O}_{20 \sim 22} \mathrm{~S}_{2}, \mathrm{C}_{45 \sim 47} \mathrm{H}_{45 \sim 49} \mathrm{~N}_{12 \sim 14} \mathrm{O}_{15 \sim 17} \mathrm{~S}_{2}, \mathrm{C}_{50 \sim 52} \mathrm{H}_{50 \sim 54} \mathrm{~N}_{13 \sim 15} \mathrm{O}_{16 \sim 18} \mathrm{~S}_{2}$ are proposed 
Tabel 2. Physicochemical properties of sulfomycin I, II and III

\begin{tabular}{|c|c|c|c|c|}
\hline & & Sulfomycin I & Sulfomycin II & Sulfomycin III \\
\hline \multicolumn{2}{|l|}{ Appearance } & $\begin{array}{l}\text { colorless amorphous } \\
\text { powder }\end{array}$ & $\begin{array}{l}\text { colorless amorphous } \\
\text { powder }\end{array}$ & $\begin{array}{l}\text { colorless amorphous } \\
\text { powder }\end{array}$ \\
\hline \multicolumn{2}{|c|}{ Nature* $\left(\mathrm{pka}^{\prime}\right)$} & $\begin{array}{l}\text { neutral or weakly acidic } \\
\quad(11.10)\end{array}$ & $\begin{array}{l}\text { neutral or weakly acidic } \\
\quad(11.30)\end{array}$ & $\begin{array}{l}\text { neutral or weakly acidic } \\
(10.90)\end{array}$ \\
\hline \multicolumn{2}{|c|}{ m. p. (decomp.) } & no decomp. over $280^{\circ} \mathrm{C}$ & $\begin{array}{l}\text { no definite m. p., } \\
\text { decomp. at about } 190^{\circ} \mathrm{C}\end{array}$ & $\begin{array}{l}\text { no definite m. p., } \\
\text { decomp. at about } 183^{\circ} \mathrm{C}\end{array}$ \\
\hline \multicolumn{2}{|l|}{$\begin{array}{c}\text { Elementary } \\
\text { analysis } \\
(\%)\end{array}$} & $\begin{array}{rrr}\mathrm{C} & 49.95, & 49.81 \\
\mathrm{H} & 4.50, & 4.49 \\
\mathrm{~N} & 16.86, & 16.64 \\
\mathrm{~S} & 4.80, & 4.58 \\
\end{array}$ & $\begin{array}{rrr}\mathrm{C} & 50.68, & 50.55 \\
\mathrm{H} & 4.25, & 4.17 \\
\mathrm{~N} & 16.14, & 16.99 \\
\mathrm{~S} & 5.81, & 5.31\end{array}$ & $\begin{array}{rrr}\mathrm{C} & 50.42, & 50.23 \\
\mathrm{H} & 4.29, & 4.32 \\
\mathrm{~N} & 16.71, & 16.14 \\
\mathrm{~S} & 5.14, & 5.46\end{array}$ \\
\hline \multicolumn{2}{|c|}{$\begin{array}{l}\text { M.W. (osmometry } \\
\text { in chloroform) }\end{array}$} & 1218,1226 & 1138, 1139 & 1233 \\
\hline \multicolumn{2}{|c|}{ Optical rotation } & $\begin{array}{l}{[\alpha]_{\mathrm{D}}^{20}-16.0^{\circ}} \\
(\mathrm{c} 2, \mathrm{MeOH})\end{array}$ & $\begin{array}{l}{[\alpha]_{\mathrm{D}}^{27}-11.8^{\circ}} \\
(\mathrm{c} 1.19, \mathrm{MeOH})\end{array}$ & $\begin{array}{l}{[\alpha]_{\mathrm{D}}^{27}+3.2^{\circ}} \\
(\mathrm{c} 2.18, \mathrm{MeOH})\end{array}$ \\
\hline \multirow{2}{*}{$\begin{array}{l}\text { Ultraviolet } \\
\text { absorption } \\
\lambda_{\max }\left(\mathrm{E}_{1 \mathrm{~cm}}^{1 \%}\right) \\
\text { (Fig. } 2)\end{array}$} & $A^{* *}$ & $\begin{array}{l}252 \mathrm{~m} \mu(712) \text { and } \\
325 \mathrm{~m} \mu(\mathrm{sh}, 110)\end{array}$ & $\begin{array}{l}252 \mathrm{~m} \mu(630) \text { and } \\
323 \mathrm{~m} \mu(\mathrm{sh}, 100)\end{array}$ & $\begin{array}{l}252 \mathrm{~m} \mu(672) \text { and } \\
324 \mathrm{~m} \mu(\mathrm{sh}, 94)\end{array}$ \\
\hline & $\mathrm{B} * *$ & $\begin{array}{l}255 \mathrm{~m} \mu(629) \text { and } \\
330 \mathrm{~m} \mu(\mathrm{sh}, 110)\end{array}$ & $\begin{array}{l}256 \mathrm{~m} \mu(549) \text { and } \\
328 \mathrm{~m} \mu(\mathrm{sh}, 103)\end{array}$ & $\begin{array}{l}253 \mathrm{~m} \mu(571) \text { and } \\
328 \mathrm{~m} \mu(\mathrm{sh}, 98)\end{array}$ \\
\hline
\end{tabular}

* On paper electrophoresis ( 10 volt/cm, 2.5 hours in $1 / 15 \mathrm{~m}$ phosphate buffer), these three components did not move from the dotted point both at $\mathrm{pH} 5.0$ and 8.0. However, on titration in $50 \%$ EtOH, sulfomycins showed weakly acidic nature.

** A : Absorption in neutral or acidic methanol. B : Absorption in alkaline methanol.

for sulfomycin I, II and III respectively. Sulfomycins are readily soluble in acetone, dioxane, dimethylformamide, dimethylsulfoxide and acetic acid, soluble in lower alcohols, esters, chloroform and in dilute sodium hydroxide solution with decomposition, hardly soluble in water, and insoluble in aliphatic and aromatic hydrocarbons and ethers. Sulfomycins are stable in neutral or weakly acidic solution, but not in strongly acidic or alkaline solution.

Sulfomycins are positive to EHRLICH reaction and decolorize potassium permanganate solution. They give initially pale brown, later changing to reddish brown coloration with conc. sulfuric acid, while they are negative to ninhydrin, biuret (brown), ferric chloride, SAKaguchi, Fehling, Benedict, Tollens, 2, 4-dinitrophenylhydrazine and concentrated hydrochloric acid reactions. $\mathrm{Rf}$ values are illustrated in Table 3. Summarized paper chromatogram of sulfomycin I is shown in Fig. 5, those of sulfomycin II and III resembling that of $\mathrm{I}$.
Fig. 2. Ultraviolet absorption spectrum of sulfomycin I, II and III.

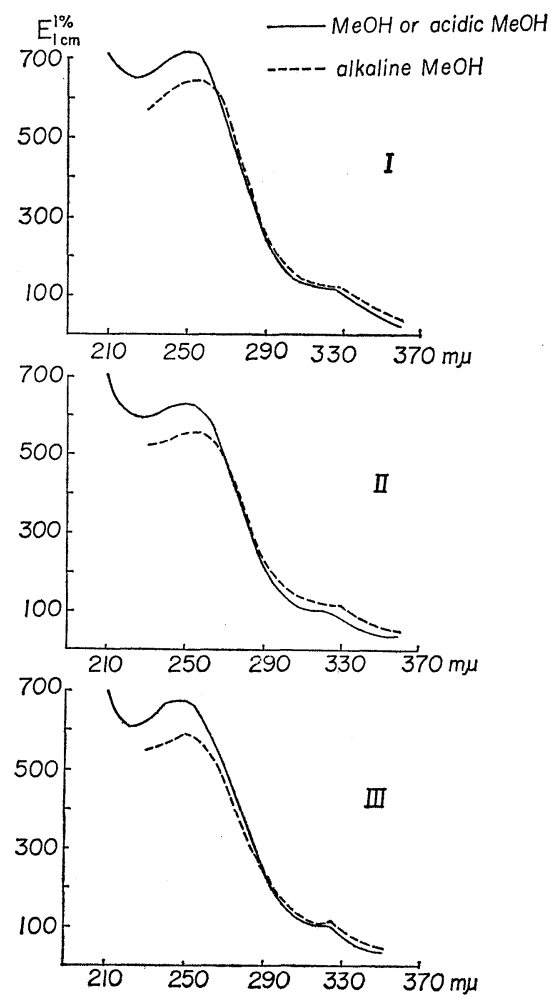


Fig. 3. Infrared spectra of sulfomycin I, II and III (Nujol)

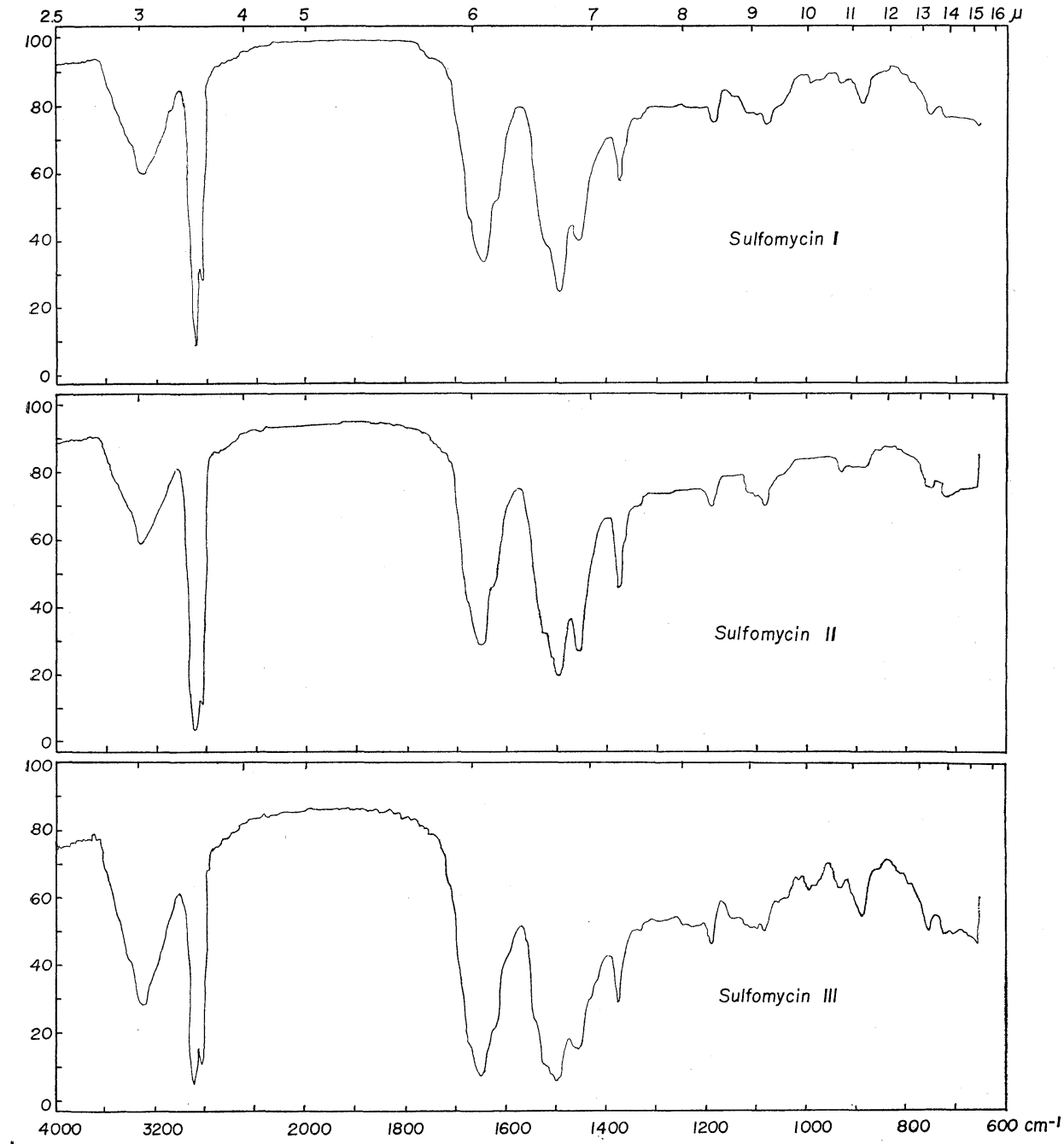

Automatic aminoacid analysis of acid hydrolysate $\left(6 \mathrm{~N} \mathrm{HCl}, 100^{\circ} \mathrm{C}\right.$ for 12 hours) of sulfomycin I and II indicated that both antibiotics gave, as main degradation products, threonine and two unidentified ninhydrin-positive substance, one being neutral in nature and giving yellow color with ninhydrin reagent, while the other being basic and coloring violet with the reagent. In addition, the presence of minor amounts of alanine and glycine was also suggested.
Table 3. Rf values of sulfomycins on paper and thin-layer chromatographies (Bioautography with B. subtilis)

\begin{tabular}{|c|c|c|c|c|}
\hline & \multirow{2}{*}{ Solvent system } & \multicolumn{3}{|c|}{ Sulfomycin } \\
\hline & & $\mathrm{I}$ & II & III \\
\hline P. C.* & $\begin{array}{l}\text { AcOEt saturated with } \\
\mathrm{H}_{2} \mathrm{O}\end{array}$ & 0.59 & 0.80 & 0.35 \\
\hline \multirow{4}{*}{ T.L.C.** } & $\begin{array}{l}n-\mathrm{BuOH} \text { saturated with } \\
\mathrm{H}_{2} \mathrm{O}\end{array}$ & 0.70 & 0.80 & 0.63 \\
\hline & $\mathrm{CHCl}_{3}-\mathrm{MeOH}(10: 1)$ & 0.38 & 0.46 & 0.30 \\
\hline & $\begin{array}{l}\text { AcOEt saturated with } \\
\mathrm{H}_{2} \mathrm{O}\end{array}$ & 0.13 & 0.26 & 0.05 \\
\hline & $\begin{array}{l}\text { AcOEt }-n-\mathrm{BuOH}(1: 1) \\
\text { saturated with } \mathrm{H}_{2} \mathrm{O}\end{array}$ & 0.87 & 0.93 & 0.84 \\
\hline
\end{tabular}

* Toyo Roshi No. $51 \mathrm{~A}$ : Ascending for 5 hours.

** Kieselgel $\mathrm{GF}_{254}$. 
Fig. 4. NMR spectrum of sulfomycin $I$ in $d_{6}$-DMSO with TMS (int.) (JEOL C-60:60 MC)

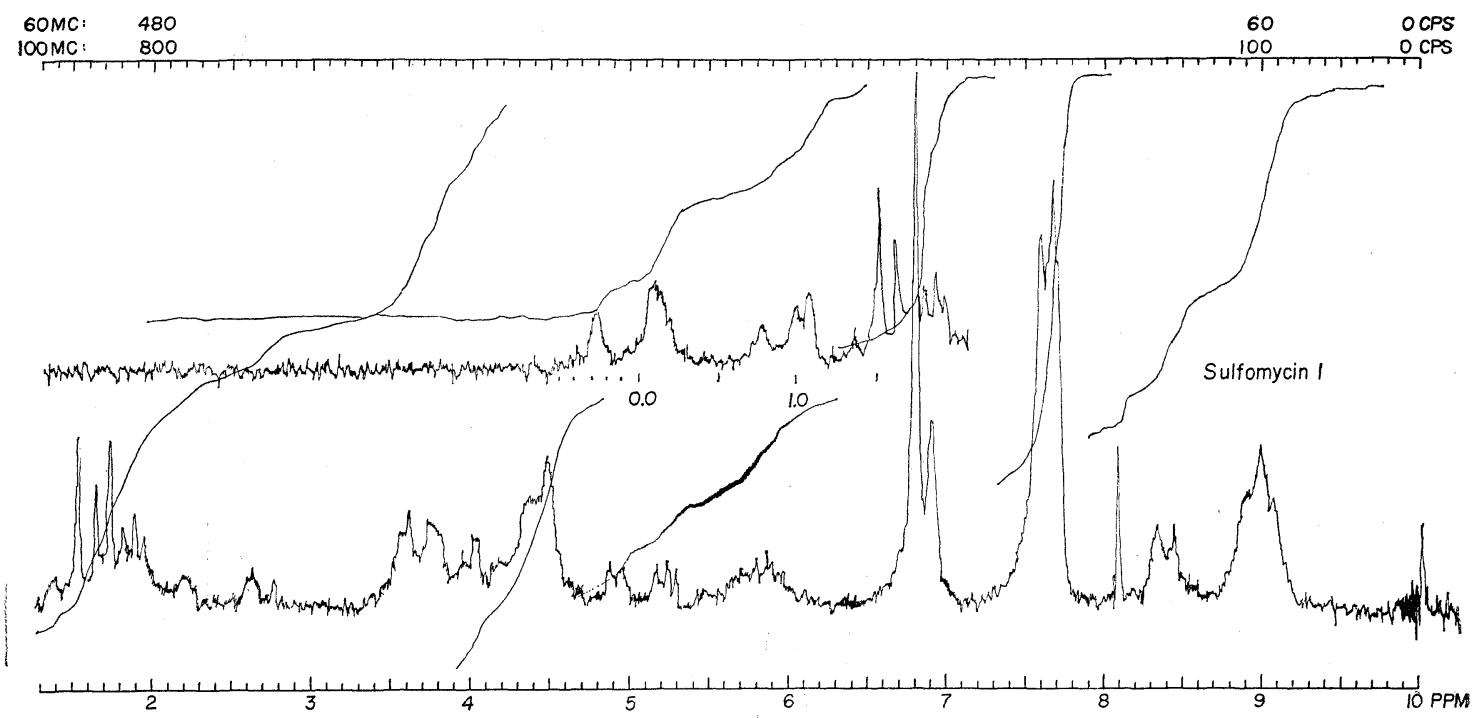

Column chromatography of the acid hydrolysate of sulfomycin I with cellulose powder (solvent systems : $n$-butanol-pyridine - water - acetic acid, $6: 4:$ $3: 1)$ gave three discrete ninhydrin-positive degradation products, $\mathrm{Rf}$ values being $0.49,0.30$ and 0.21 (thin-layer chromatography on cellulose powder plate with solvent system as above). Substance with Rf 0.30 was identified as threonine and the others have not been identified yet. In addition, one unidentified ninhydrin-negative sulfur-containing substance was also isolated from the acid hydrolysate of sulfomycin I. Characterization of these unidentified substances is under study.

\section{Biological Properties}

Antimicrobial activities of sulfomycins are listed in Table 4. As evident from the table, they are strongly active against Gram-positive cocci and bacilli, mycoplasma and anaerobic bacteria, and weakly active against Neisseria, Bordetella and mycobacteria. But, they are inactive against Escherichia,

Fig. 5. Summarized paperchromatogram of sulfomycins (Bioautography with $B$. subtilis) Solvent :

A : wet $n-\mathrm{BuOH}$

B : $20 \%$ ammonium chloride aq. solution

D: $50 \%$ aq. acetone

$\mathrm{E}: n-\mathrm{BuOH}(40 \mathrm{ml})-\mathrm{MeOH}(10 \mathrm{ml})-$ $\mathrm{H}_{2} \mathrm{O}(20 \mathrm{ml})+$ methylorange $(1.5 \mathrm{~g})$

$\mathrm{F}: n-\mathrm{BuOH}(40 \mathrm{ml})-\mathrm{MeOH}(10 \mathrm{ml})-$ $\mathrm{H}_{2} \mathrm{O}(20 \mathrm{ml})$

$\mathrm{G}$ : benzene - $\mathrm{MeOH}(4: 1)$

$\mathrm{H}: \mathrm{H}_{2} \mathrm{O}$

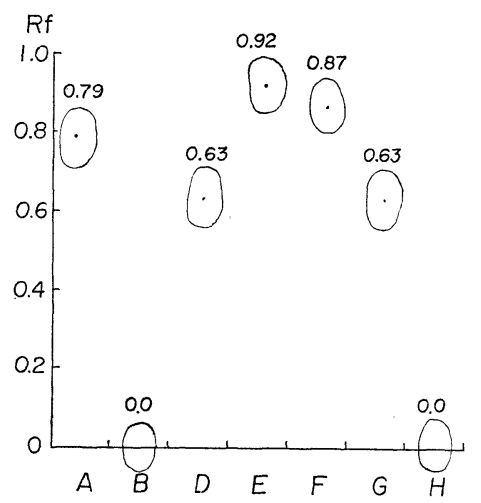

Pseudomonas, fungi and yeast. They are active as well against strains resistant to penicillin, streptomycin, tetracycline and chloramphenicol and also against staphylococci freshly isolated from the clinical material at concentration of $0.19 \sim 0.39 \mathrm{mcg} / \mathrm{ml}$. However, they showed cross resistance with bryamycin (thiostrepton).

Mice tolerated to the intraperitoneal administration of $400 \mathrm{mg} / \mathrm{kg}$ of sulfomycin I and III or $100 \mathrm{mg} / \mathrm{kg}$ of sulf omycin II. Survival eff ects were observed in mice infected 
intraperitoneally with the mucin-added diffuse type of Staphylococcus aureus Smith, minimum effective dose of sulfomycins given intraperitoneally being $1.25 \mathrm{mg} / \mathrm{kg}$ for sulfomycin I and II, and $1.25 \sim 2.5 \mathrm{mg} / \mathrm{kg}$ for sulfomycin III.

\section{Discussion}

On the basis of biological properties, sulfomycin seemed to be related to the previously reported sulfur-containing peptidic antibiotics, bryamy$\operatorname{cin}^{1)}$ (thiostrepton ${ }^{2)}$ ), siomy$\operatorname{cin}^{3)}$, pepthiomycin $\mathrm{A}$ and $\mathrm{B}^{4)}$ and substance A 595). However, the above mentioned physicochemical properties of sulfomycins, especially aminoacid constitution and elementary analysis data, readily differentiate sulfomycins from these antibiotics and also from any of other known sulfurcontaining antibiotics. Thus, the sulfomycins have been concluded to be a series of new sulfur-containing peptidic antibiotics.
Table 4. Antimicrobial activity of sulfomycins

\begin{tabular}{|c|c|c|c|}
\hline \multirow{2}{*}{ Test Organisms* } & \multicolumn{3}{|c|}{ MIC $(\mathrm{mcg} / \mathrm{ml})$ of sulfomycin } \\
\hline & I & II & III \\
\hline Staphylococcus aureus FDA 209P & 0.19 & 0.19 & 0.78 \\
\hline Terashima & 0.19 & 0.19 & 0.78 \\
\hline Smith & 0.19 & 0.19 & 0.78 \\
\hline $\mathrm{R} 1$ & 0.19 & 0.19 & 0.78 \\
\hline $\mathrm{R} 2$ & 0.19 & - & - \\
\hline $\mathrm{R} 3$ & 0.09 & - & - \\
\hline $\mathrm{R} 4$ & $>25$ & $>25$ & $>25$ \\
\hline Streptococcus hemolyticus & 0.04 & 0.09 & 0.19 \\
\hline Diplococcus pneumoniae & 0.04 & 0.09 & 0.39 \\
\hline Bacillus subtilis PCI 219 & 0.09 & 0.09 & 0.39 \\
\hline $\begin{array}{l}\text { Corynebacterium diphtheriae } \\
\text { Park-Williams No. } 8\end{array}$ & 0.02 & 0.09 & - \\
\hline Bordetella pertussis Tohama & $\begin{array}{r}6.25 \\
(48 \mathrm{hr})\end{array}$ & $\begin{array}{r}6.25 \\
(48 \mathrm{hr})\end{array}$ & - \\
\hline Neisseria meningitidis 13077 & 6.25 & 6.25 & - \\
\hline 13090 & 0.78 & 0.78 & - \\
\hline Clostridium tetani & 0.39 & 6.25 & - \\
\hline Clostridium welchii & 3.0 & 12.5 & - \\
\hline Mycobacterium tuberculosis $\mathrm{H}_{37} \mathrm{Rv}$ & $\begin{array}{c}25.0 \\
(3 \text { weeks })\end{array}$ & $\begin{array}{c}25.0 \\
(3 \text { weeks })\end{array}$ & - \\
\hline Escherichia coli NIHJ & $>25$ & $>25$ & $>25$ \\
\hline Pseudomonas aeruginosa & $>25$ & $>25$ & $>25$ \\
\hline Aspergillus niger & $>25$ & $>25$ & $>25$ \\
\hline Penicillium notatum & $>25$ & $>25$ & $>25$ \\
\hline Candida albicans & $>25$ & $>25$ & $>25$ \\
\hline Saccharomyces cerevisiae & $>25$ & $>25$ & $>25$ \\
\hline Mycoplasma galisepticum & $\begin{array}{r}0.06 \\
(48 \mathrm{hr})\end{array}$ & - & - \\
\hline
\end{tabular}

* R 1 : penicillin, streptomycin, tetracycline and chloramphenicol-resistant strain

R 2 : amphomycin-resistant strain

R 3 : telomycin-resistant strain

R 4 : bryamycin-resistant strain

Acknowledgement

The authors express their thanks to Dr. KeIshi Kotera and his collaborators of the Analysis Center and to Dr. Kenji Masukawa and his associate of Product Control Laboratory of this company for their physicochemical services. They also thank to Mr. Tотаво Yamaguchi who kindly afforded us the soil sample from which the sulfomycin-producing strain was isolated.

\section{References}

1) Cron, M. J.; D. F. Whitehead, I. R. Hooper, B. Heinemann \& J. Lein : Bryamycin, a new antibiotic. Antibiot. \& Chemoth. 6:63 67, 1956

2) Vandeputte, J. \& J. D. Dutcher: Thiostrepton, a new antibiotic. II. Isolation and chemical characterization. Antibiot. Ann. 1955/1956 : 560 561, 1956.

3) Nishimura, H.; S. Окаmoto, M. Mayama, H. Ohtsuka, K. Nakajima, K. Tawara, M. Shimohira \& N. Shimaoka: Siomycin, a new thiostrepton-like antibiotic. J. Antibiotics, Ser. A $14: 255$ $\sim 263,1961$

4) Mizuno, K.; M. Hamada, K. Maeda \& H. Umezawa : Pepthiomycin, a new peptide antibiotic mixture. J. Antibiotics $21: 429 \sim 431,1968$

5) Kondo, S.; E. Akita, J. M. J. Sakamoto, M. Ogasamara, T. Nitda \& T. Hatakeyama: Studies on a new antibiotic produced by Streptomyces sp. A-59. J. Antibiotics, Ser. A $14: 194 \sim 198,1961$ 